\title{
Brakeman or booster? Presidents, ideological polarization, reciprocity, and the politics of US arms control
}

\section{Florian Böller ${ }^{1}[$}

Accepted: 24 June 2021 / Published online: 7 July 2021

(c) The Author(s) 2021

\begin{abstract}
US arms control policies have shifted frequently in the last 60 years, ranging from the role of a 'brakeman' regarding international arms control, to the role of a 'booster,' initiating new agreements. My article analyzes the conditions that contribute to this mixed pattern. A crisp-set Qualitative Comparative Analysis (QCA) evaluates 24 cases of US decisions on international arms control treaties (1963-2021). The analysis reveals that the strength of conservative treaty skeptics in the Senate, in conjunction with other factors, has contributed to the demise of arms control policies since the end of the Cold War. A brief study of the Trump administration's arms control policies provides case-sensitive insights to corroborate the conditions identified by the QCA. The findings suggest that conservative treaty skeptics contested the bipartisan consensus and thus impaired the ability of the USA to perform its leadership role within the international arms control regime.
\end{abstract}

Keywords International treaties · Arms control · US foreign policy · QCA

\section{Introduction}

During the four years of his presidency, Donald Trump canceled several important international treaties and agreements, including the Paris Climate Accord, the Trans-Pacific Partnership, the Iran Nuclear Deal, the Intermediate-range Nuclear Forces Treaty (INF), and the Open Skies Treaty. In fact, withdrawing from international commitments and multilateral institutions was a core element of the 45th US president's 'America First' doctrine (see Schultz, 2017; Amirfar and Singh, 2018). To be sure, skepticism against binding treaties and putting national interests first have been recurring themes of US politics and were not invented by Trump. President Bill Clinton, for example, was not able to convince a majority in the Senate to ratify the Comprehensive Test Ban Treaty (CTBT) in 1999, and President

Florian Böller

boeller@sowi.uni-kl.de

1 Department of Political Science, University of Kaiserslautern, Kaiserslautern, Germany 
George W. Bush withdrew from the Anti-ballistic Missile Treaty (ABM) in 2002. In all these instances, the USA acted as a 'brakeman' to international cooperation. On the other hand, the USA has at times boosted international institutions in various policy fields, including arms control, for example with the Strategic Arms Limitations Talks (SALT $1 \&$ 2) during the Cold War, and, more recently, under President Barack Obama's leadership, with the New Strategic Arms Reduction Treaty (New START) of 2010, and the Joint Comprehensive Plan of Action (JCPOA) to contain Iran's nuclear ambitions in 2015.

My article seeks to analyze the conditions that contribute to this shifting pattern of ranging from a 'brakeman' to a 'booster' role in the field of international treaties. More specifically, I examine the politics of US arms control policy by integrating insights from domestic politics, in particular the role of partisanship and ideology, and international relations, which highlights the perception of reciprocity and the international setting in which treaties are concluded. In the empirical part of this article, I introduce a novel dataset and employ the method of crisp-set Qualitative Comparative Analysis (QCA) to evaluate 24 cases of international arms control treaties' inception and break-up, from 1963 to 2021, beginning with the Limited Test Ban Treaty (LTBT), up until the decision to extend the New START treaty under the Biden Administration. To corroborate the conditions identified by the QCA, I focus on President Trump's arms control policies, and the factors and processes leading to the withdrawal from several agreements.

Scholars have previously investigated both the domestic side of US treaty politics (see i.a. Krutz and Peake, 2009; Lantis, 2009; Kreps et al., 2018) and its international repercussions (see i.a. Müller and Wunderlich, 2013). My analysis contributes to this literature by connecting insights into the effect of ideological polarization in US politics to the field of treaty politics.

\section{The domestic and international sides of US treaty politics}

Previous research on US behavior in the field of arms control and nuclear non-proliferation policies can be approximately divided into two strands. One focuses on the domestic conditions that shape foreign policy decision making, and the other addresses international factors that drive the US role in this policy area. In this section, I consider the domestic side of US treaty politics, before I turn to the international aspects.

A first reason why it is important to consider the domestic side of US foreign policy (and in particular in the area of arms control) can already be found in the US Constitution and its system of 'checks and balances.' In Article 2, Sec. 2, clause 2, the constitution grants both the president and the Senate key roles regarding international treaties and agreements: 'He (the president) shall have Power, by and with the Advice and Consent of the Senate, to make Treaties, provided two-thirds of the Senators present concur.' Accordingly, presidents can initiate international agreements and negotiate their content, but need a two-thirds majority in the Senate to ratify the treaty (see Glennon, 1990). The Senate, and in particular its Foreign Relations Committee, usually seek an active role by holding public hearings, closed sessions, 
and floor debates throughout the 'advice and consent' procedure. Therefore, achieving the ratification of a treaty consumes significant political capital and involves building a bipartisan coalition to overcome the two-thirds hurdle. In recent years, presidents have sought to circumvent this threshold by concluding executive agreements, instead of treaties, which have relatively similar impact, but lack the domestic commitment (Prins and Marshall, 2009). Examples of executive agreements in the field of arms control include the 2015 JCPOA and the 1994 Agreed Framework with North Korea.

In contrast to the US constitution's clear stipulation regarding the ratification process, there is still debate about which institutions have a say in the dissolution of agreements. This question often evolves into a political struggle that goes beyond mere constitutional considerations. For example, when President Carter unilaterally terminated the bilateral security treaty with Taiwan in 1979, the US Supreme Court declined to review the president's decision and thus left the constitutional question of treaty annulment unanswered (see Glennon, 1990). Against the backdrop of Trump's pondering with withdrawing the USA from NATO, several non-binding resolutions were passed with bipartisan majorities in Congress, to signal the legislative branch's intent to contest any attempt to break up the 1949 Washington Treaty (see i.a. Sec. 1248.a, P.L. 115-232). Although it is unclear whether both sides of the aisle would have summoned a veto-proof majority, the example of NATO highlights that treaty dissolution (as well as ratification) entails a political process in which the president and Congress struggle to achieve a dominant position (see Deibel, 2002; Kelley and Pevehouse, 2015).

A significant amount of scholarship has been devoted to the increasing polarization of the US political system. While the divide between the Republican and the Democratic Party is more distinct in domestic politics, the old paradigm according to which 'politics stops at the water's edge' seems to be no longer valid. According to research by Kupchan and Trubowitz (2007), the proportion of bipartisan foreign policy votes decreased significantly between 1945 and 2005. To explain this finding, the authors point out that ideological polarization increased, and moderate members of Congress, who formed the core of a 'liberal consensus' within the legislative branch, disappeared. While Chaudoin et al. (2010) dismiss the thesis of a 'dead center,' and rather argue that 'the center still holds,' more recent scholarship has also revealed a growing ideological gap that applies to foreign policy decisions in Congress (Jeong and Quirk, 2019). In a similar vein, DeLaet and Scott's (2006) analysis of security treaty ratification identifies growing polarization in Congress since the end of the Cold War. Other studies note that ideology has a significant influence on voting decisions by members of Congress (see Auerswald, 2006; Peake et al., 2012).

Between 1948 and 2020, there were 33 roll call votes to ratify international treaties in the realm of security policy. ${ }^{1}$ Figure 1 compares the share of 'no' votes in the US Senate, before and since the end of the Cold War. While there is no discernable trend toward increasing contestation, the level of support for the agreements varies considerably, and it is clear that at least some agreements were subject to domestic

\footnotetext{
1 Several treaties were also passed by voice or division vote, which denotes the absence of politicization.
} 


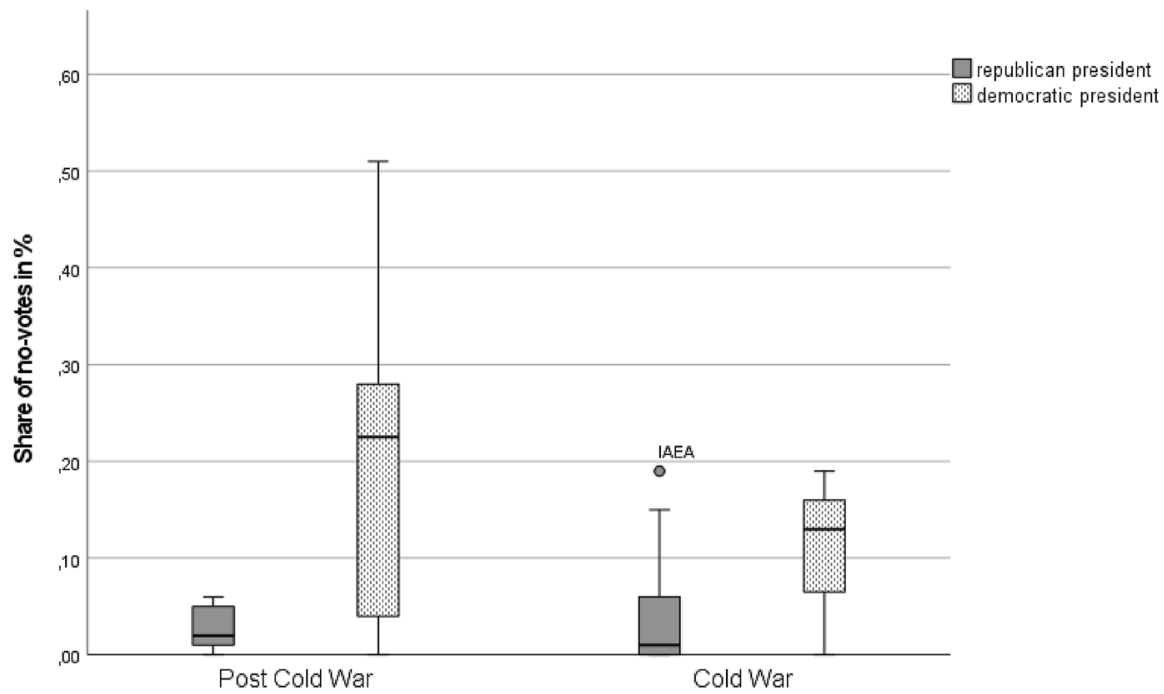

Fig. 1 Share of 'No' Votes in the US Senate on Security Treaties (1948-2020). Source: Own calculation; voting data retrieved from Voteview.com

contestation. Controlling for the partisanship of the president, the Cold War, and arms control as an issue area, an ANOVA test shows that the share of 'no' votes was significantly higher under Democratic presidents. ${ }^{2}$ This finding is also in line with a recent study by Kreps et al. (2018: 495), which revealed that Democratic presidents may face higher domestic hurdles for arms control treaty ratification.

The recent literature, as well as the brief empirical spotlight on treaty ratification votes in the Senate, suggests that it is important to consider the partisan composition and the ideological orientation of both the presidency and the Congress, since the two branches play a key role in this policy field, which has become subject to domestic contestation.

International conditions also affect US treaty politics. Realist accounts of international relations contend that states need to focus on threats to their security and seek to advance national interests. International cooperation is hence always subject to the 'shadow of the future' (Powell, 1991), in which today's partners might turn into enemies. States will therefore consider whether international agreements produce relative gains for adversaries (see Kühn, 2020: 46). Institutionalist approaches, on the other hand, highlight the possibility of positive-sum games and claim that actors enter regimes if they perceive the partner as trustworthy, and the commitments as reciprocal and fair (see Axelrod and Keohane, 1985). Both insights are relevant for

\footnotetext{
${ }^{2}$ The difference for votes during Democratic presidencies was significant $\left(p<0.01\right.$; partial $\left.\eta^{2} 0.252\right)$. Variables arms control and Cold War were not significant $(p>0.05)$. The analysis of roll call votes also shows that strategic arms control treaties received on average less "no" votes $(8.5 \%)$ compared to nonstrategic arms control treaties $(9.6 \%)$. However, the difference is statistically not significant $(T$ test, $p>0.05)$.
} 
the area of arms control, in particular regarding weapons of mass destruction, where betrayal might lead to mutual destruction, so the international setting in which treaties and agreements are concluded, is significant. The regime's complexity, both its functional scope and its inclusiveness, influence the win-sum for domestic ratification. Domestic actors will only accept agreements which are seen as fair. A reciprocal 'tit for tat' (Axelrod, 1984) in arms control agreements, which is not biased in favor of one party, is therefore more likely to be supported by domestic veto players.

\section{Research design and operationalization of conditions}

Drawing from both the domestic and the international context, I consider four conditions that explain whether the USA adopts a 'brakeman' position (i.e., withdraws or rejects treaties) or a 'booster' position (i.e., supports and renews treaties). I test those conditions by applying the method of crisp-set Qualitative Comparative Analysis (QCA).

QCA is a burgeoning method in the social sciences and Foreign Policy Analysis (see i.a. Haesebrouck and Immerseel, 2020; Mello, 2021). A set of cases is analyzed, using Boolean algebra, to identify necessary and sufficient conditions for an expected outcome. Rather than calculating the relative effect of variables, distinct (sets of) conditions can lead to specific outcomes. In other words, there are various pathways resulting in social phenomena. At the same time, the absence of an outcome may be connected to different conditions (Mello, 2021: 176). Many empirical events in IR entail such complex combinations of causal factors. This is why QCA is particularly suited to the investigation of US treaty politics, where one can expect events to be caused by varying domestic and international conditions. QCA allows this topic to be studied in a case-oriented and comparative approach.

In the following QCA, the 24 cases are assigned membership scores along their specific conditions, on a two-value set (bivalent crisp QCA, with values 0 or 1). Based on the criteria outlined below, a case is either in or not in a given set of outcomes and conditions. For some indicators, there is a clear criterion to distinguish between the presence and absence of a case in a certain set. For example, states may be members of the UN Security Council, but they cannot be "more out of than in' the set. In other cases, researchers need to rely on theoretical knowledge, and use qualitative as well as quantitative indicators, to calibrate the sets, and assign the membership scores. However, as most conditions, and the outcome, refer to bivalent concepts, I apply a consistent crisp-set analysis, rather than a fuzzy-set QCA.

\section{Case selection}

As this article addresses the conditions of US positioning toward international arms control policies and regimes, relevant cases include the conclusion of international treaties on weapons of mass destruction (both strategic and non-strategic systems), and conventional weapons, as well as decisions to withdraw from existing agreements. While the cases thus include distinctive features, I argue that the political 
debate on diverse weapons systems is oftentimes interrelated. For example, the CTBT was criticized for its supposedly negative impact on the reliability of the US strategic arsenal. Hence, despite these differences, a comparative analysis may yield relevant insights into the politics of US arms control policies.

To capture the universe of cases, I use the comprehensive list of international arms control agreements compiled by the non-partisan Arms Control Association (Arms Control Association, 2020). From this list, I exclude all regional nuclearweapons-free zone treaties (Treaty of Tlatelolco 1967, Treaty of Rarotonga 1985, Treaty of Pelindaba 1996), to which the USA is not a relevant party. I also do not code the Peaceful Nuclear Explosions Treaty as a separate case, as the agreement was part of the Threshold Test Ban Treaty (TTBT). Consistent with that coding decision, I define the conclusion of the ABM Treaty and the Interim Agreement as a single case, since they were both part of the umbrella Strategic Arms Limitation Talks (SALT 1). Finally, I code the withdrawal from existing treaties as separate cases, if they had already come into force (this applies to the termination of the ABM treaty under President Bush in 2001, and Trump's withdrawal from the INF and Open Skies treaties in 2018 and 2020). I also do not consider international agreements which were not proper international treaties, such as the JCPOA. Since these executive agreements do not require a two-thirds majority in the Senate, underlying processes and domestic politics render a systematic comparison within the present research design problematic. In particular, the role of political polarization in the Senate can be expected to vary significantly between treaties and executive agreements. The result is a set of 24 cases (see Table 1).

From a methodological perspective, QCA focuses explicitly on making sense of specific cases (see Schneider and Wagemann, 2010: 5). In contrast to many quantitative research designs, for example, regressions analyses, which aim at estimating the likelihood of certain events and decisions, QCA researchers usually avoid probabilistic statements when interpreting their results (see Mello, 2021: 19), so it is difficult to deduct generalized statements with no corresponding cases, or detect the conditions for non-decisions. Admittedly, this restriction also applies to treaty politics. It could be argued that the decision to continue to be a member of a treaty represents a 'non-decision to withdraw.' Focusing on actual decisions to enter and withdraw from treaties may seem skewed from this perspective. Bearing this caveat in mind, the following analysis nonetheless offers insights by investigating the sufficient and necessary conditions for the specific cases under investigation.

\section{Outcome}

The outcome for this analysis is the positioning of the USA as a 'brakeman' (label: B) toward arms control treaties. If the USA unilaterally withdraws from an existing agreement, or refuses to sign a new treaty, the case is assigned to the set 'brakeman' (value 1). If the USA signs but does not ratify a treaty, the case is also considered to be in the set 'brakeman,' because arms control treaties become binding for the signatory state only if they are ratified by the respective domestic institution, in this case, the US Senate. Since the USA is still the most powerful state in terms of 


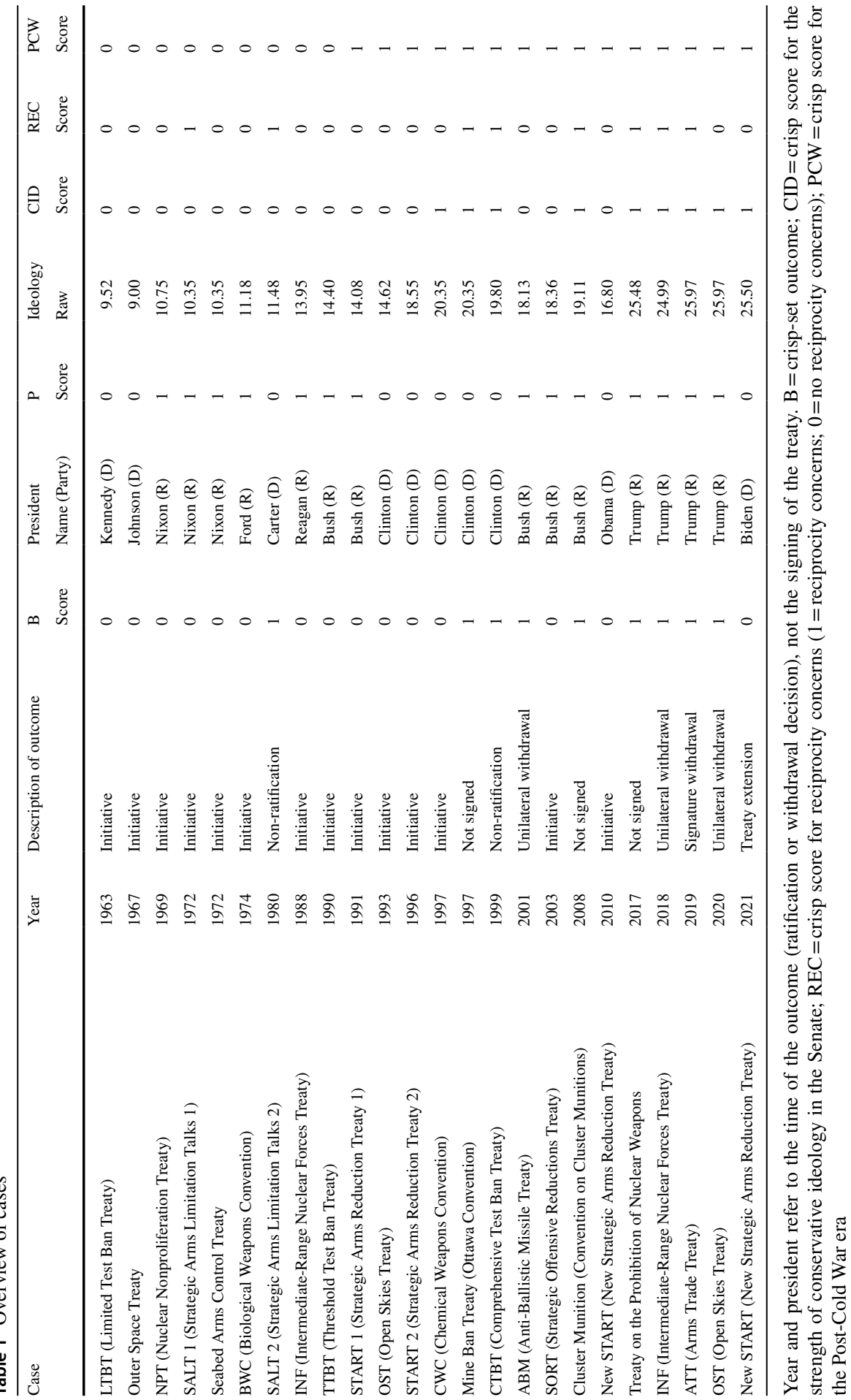

然 
military and economic resources, and has traditionally played the role of a 'guardian of the liberal world order,' withdrawal decisions, or refusal to support new cooperative institutions, influence the efficacy and legitimacy of the regime (see Friedrichs, 2021). In contrast to a 'brakeman' role, the USA may also act as a 'booster' of international cooperation. This is the case if the USA takes the initiative to introduce new arrangements. Also, if the USA decides to extend existing treaties, it performs a 'booster' role for global arms control regimes.

\section{Conditions}

Four conditions are considered, to explain the outcome. These conditions reflect the domestic and international sources of treaty politics, outlined in the previous section.

The first condition addresses the argument that presidents and their ideology matter ('President,' label: P). While post-World War II presidents exhibit a diverse track record regarding international institutions, I hypothesize that the conservative ideology of Republican presidents may lead to the adoption of a 'brakeman' position. It can be assumed that conservative politicians focus on military primacy, rely on unilateralism as a strategic policy option, and underscore the importance of 'peace through strength' (Ronald Reagan, cited in Cannon, 1980), rather than through multilateralism and international cooperation. This assumption is also supported by comparative research both for the USA, and for other democracies (see Gries, 2014; Lewis, 2017: 51; Wenzelburger and Böller, 2020). I do not suggest that Republican presidents will never enter international arms control treaties, while Democratic presidents will be happy to sign whatever is presented for signature. Rather, as Kreps et al. (2018: 492) point out, Democratic presidents may encounter higher domestic hurdles to treaty ratification. The argument here is that their more 'dovish' ideological orientation may incite criticism from 'defense hawks' in Congress, who are skeptical of binding arms control commitments.

The second condition ('Conservative Ideology,' label: CID) takes the aspect of ideology in the Senate into account. Due to the institutional hurdle of a two-thirds majority, the ratification of international treaties requires bipartisan support in the Senate. While, in general, a broad majority for the party of the president in the Senate might help to win the ratification of a treaty, it could also mute congressional assertiveness against the break-up of an international commitment, so it is important to consider the directional expectation of the ideological composition of the Senate. In line with the consideration of presidential ideology, the historical track record reveals that conservative Republicans in Congress have been most skeptical of international obligations (see Kühn, 2019). For example, during the consideration of the League of Nations and NATO treaties, conservatives argued in favor of national sovereignty, and against binding international commitments (Rathbun, 2011; see also Busby et al., 2020: 126). President Obama's arms control deal with Iran in 2015 may also serve as a case in point. Republican opposition against the agreement foreclosed its ratification in the Senate (see Homan and Lantis, 2020: 182). Obama was therefore only able to conclude an executive agreement, arguably diminishing the 
reliability of the commitment. Moreover, since the 1980s, conservatives in Congress have pushed for a termination of the ABM treaty, in order to realize their long-term policy goal of a missile defense system (see Kubbig, 2005).

The second condition is operationalized by employing the established DW nominate data's first dimension scores (see Lewis, et al., 2020). I multiplied the average ideology score of all Republican senators with their number of seats. The argument is that the strength of conservative treaty skeptics in the Senate-in terms of their number and ideological orientation - may contribute to the adoption of a 'brakeman' position of the USA, for example by blocking treaty ratification, or by pushing for policies that run counter to existing agreements. ${ }^{3}$

Conditions three and four address the international environment. Condition three considers whether treaties rest on the principle of reciprocity ('Lack of Reciprocity,' label: REC). The perception of the USA that cooperation partners receive relative gains from treaties, may induce the rejection of, or withdrawal from, a treaty (see Lantis, 2009: 199). For example, the SALT 1 Interim Agreement drew significant criticism by members of Congress, as it entailed a lower limit for nuclear weapons for the USA than for the Soviet Union. Although it could be argued that loopholes in the agreement allowed the USA to close the gap in nuclear warheads (by 'MIRVing' their existing missiles), Congress passed a resolution demanding that future agreements must not entail inferior limits for the US side (see Chiampman, 2018). A lack of reciprocity may also apply to a situation in which a treaty party violates an existing agreement. Regarding the INF treaty, both the Obama and the Trump administration accused Russia of circumventing the treaty's ban on developing new medium-range missiles. Such accusation, and the resulting perception of lacking reciprocity, often remain contested. It is therefore important to assess carefully whether there actually is a clear lack of reciprocity. A case is assigned to the set 'lack of reciprocity' if the treaty entails asymmetrical provisions for an adversary major power (such as in the case of SALT1), does not include all major powers, ${ }^{4}$ or if there is a bipartisan consensus that an actor is in violation of its commitments (e.g., in the case of the INF and the SALT 2 treaties). ${ }^{5}$

Condition four addresses the international level of major power rivalry, and the resulting polarity of the international system. I hypothesize that during the Cold War, the bipolar system generated relative stability between the two superpowers and enabled the conclusion of arms control treaties 'on a level playing field' (see i.a. Mearsheimer, 1990: 51). As Müller (2000: 81) notes, 'in bipolarity, the two leading states develop strong interests that their strategic rivalry should not get out of hand,' and result in mutual destruction. After the end of the Cold War, arms control became more complex, as new powers emerged. Even though Russia and the USA

\footnotetext{
3 The 0.5 threshold for this condition is assigned by using a qualitative anchor. I argue that ideological polarization reached a new level after the 'Republican Revolution' (see Busby and Monten, 2008: 459). Therefore, the score for the year 1995, the first year after the Republican victory in the 1994 elections, serves as the 0.5 anchor (raw value 18.9). For robustness checks, see the appendix.

${ }^{4}$ This may result in relative gains for the unconstrained actors, for example, in the case of the CTBT, which was not signed by all other nuclear weapon states.

${ }^{5}$ More detailed coding justification is outlined in the appendix.
} 
still possess circa 90 percent of the nuclear arsenal worldwide (SIPRI, 2021), the shifting international environment impacts US debates on arms control. In particular, China is perceived as a relevant player, despite its limited nuclear capabilities. Furthermore, the post-Cold War era is defined by 'strategic uncertainty' (Gabel, 2004: 192) due to varying threat perceptions, for example, regarding rogue states and terrorism. The international setting arguable also affects domestic politics. Without the prevalent consensus on critical threats of the Cold War era, bipartisanship on foreign policy in Congress began to wane (Kupchan and Trubowitz, 2007: 27). Therefore, it is possible to deduce that being in the post-Cold War era may be a relevant condition contributing to the adoption of a 'brakeman' role by the USA ('Post-Cold War,' label: PCW). The threshold here is the year 1991, when the Soviet Union was dissolved (Table 2).

\section{Results and discussion}

A first look at the data lets us trace the development of US positioning toward arms control agreements (see Fig. 2). During the Cold War era, the USA initiated several important treaties, in particular together with the Soviet Union on nuclear arms control. The only exception before the end of the Cold War is the failed ratification of the SALT 2 agreement in 1980, under President Carter. The US position became more tilted toward a 'brakeman' role in the late 1990s, with the refusal to sign the Mine Ban Treaty, and the rejection of the CTBT by the Senate in 1999, under President Clinton. During the George W. Bush administration, the unilateral termination of the ABM treaty in 2001, as well as the opposition toward the Cluster Munition Treaty in 2008, presented cases of a 'brakeman' role. At the same time, the record became more mixed after the end of the Cold War, as the USA still boosted several arms control commitments during the George H. W. Bush, Clinton, and Obama administrations. Even under the presidency of George W. Bush, an arms control agreement with Russia, the Strategic Arms Reduction Treaty (SORT), was concluded. In a shift toward full-blown opposition against arms control regimes, the Trump administration dissolved two major treaties (Open Skies, INF) and stated its opposition to the Nuclear Prohibition Treaty. Trump also withdrew his predecessor's signature to the Arms Trade Treaty (ATT). It is not part of this analysis, but, in line with Trump's 'America First' doctrine, the administration also worked to undermine the Iran nuclear deal.

In contrast to the Trump administration's apparent repudiation of binding international commitments, President Joseph R. Biden has moved swiftly to reverse his predecessor's treaty politics. In the area of arms control, Biden decided to extend the New START treaty concluded under Obama (see White House, 2021). As the treaty included a sunset provision, an active decision by both parties was necessary for its extension. The Trump administration had previously stated its intent to renegotiate New START, instead of prolonging the last remaining US-Russian arms control regime (see Washington, 2021).

This mixed record suggests a complex pattern, which cannot be explained by individual factors-such as the partisanship of presidents, or the issue area of a 
treaty. QCA is therefore an appropriate method to grasp the multifaceted policy field and reveal several possible paths that lead to the conclusion or break-up of arms control treaties.

The QCA calculation for this dataset was performed with R, a software environment for statistical computing, and the QCA package for R, version 3.11 (Dusa, 2019). I note for the conjunction of conditions (logical AND) '*, for disjunctions (logical OR) ' + ,' and the negation ' $\sim$.'

The analysis starts by assessing potential necessary conditions (see Table 3 ). Of all conditions, only the absence of a lack of reciprocity ( REC) exceeds the expected threshold of 0.9 in consistency with the non-outcome ('booster' role of the USA). This supports the argument that arms control agreements were only entered into, if they were based on reciprocal terms. However, on closer inspection, SALT 1 represents a deviant case for this assumption, since the USA joined the treaty, despite its lack of reciprocity. Therefore, the condition cannot be regarded as necessary for the outcome of a 'booster' role of the USA.

The next step of the QCA is to compile a 'truth table' of all combinations of conditions and the corresponding cases. Researchers then need to evaluate whether each set of conditions is sufficient for the outcome (see Table 4). The consistency measure (Con) is the main indicator of a combination of sufficient conditions. I follow QCA conventions and assume that an outcome is present, if the consistency is above 0.75 (see Schneider and Wagemann, 2012: 185).

Furthermore, the truth table reveals six specific combinations of conditions for which there were no empirical cases (logical remainders). It should also be noted that the 'brakeman' role entails fewer cases (9) than the 'booster' role (15).

Depending on whether logical remainders (combinations of conditions without corresponding cases) are included, the analysis produces a parsimonious, an intermediate, and a complex solution. For this analysis, I use the parsimonious solution, which also includes logical remainders for the outcome. Following recommendations of good practice in QCA (see Mello, 2021; Schneider and Wagemann, 2012), I inspect the parsimonious solution term for untenable assumptions, producing an 'enhanced parsimonious solution' (Dusa, 2019: 190). ${ }^{7}$

Accordingly, the truth table algorithm reveals two paths for a 'brakeman' position (see Table 5 and Fig. 3). First, the perception of a treaty as not reciprocal, combined with a Democratic president, is sufficient for the adoption of a 'brakeman' position $(\sim \mathrm{P} * \mathrm{REC} \rightarrow \mathrm{B})$. This solution term accounts for the defeat of the CTBT treaty in 1999, and the refusal to sign the Ottawa Convention in 1997 (Mine Ban), during the Clinton administration. The USA perceived participation in these multilateral regimes as unfair, since other major powers, such as China and Russia, were not prepared to join the treaties. Treaty skeptics within the Republican party, which controlled the Senate majority in the 106th Congress with 55 seats, ensured that these treaties would not be ratified. During the debates on the CTBT, Senator Jim Inhofe's (R-OK) statement illustrates this perception: '(this treaty) allows our adversaries to

\footnotetext{
${ }^{6}$ Full documentation of the QCA and replication data are provided on separate file.

7 See the appendix regarding the use of logical remainders.
} 


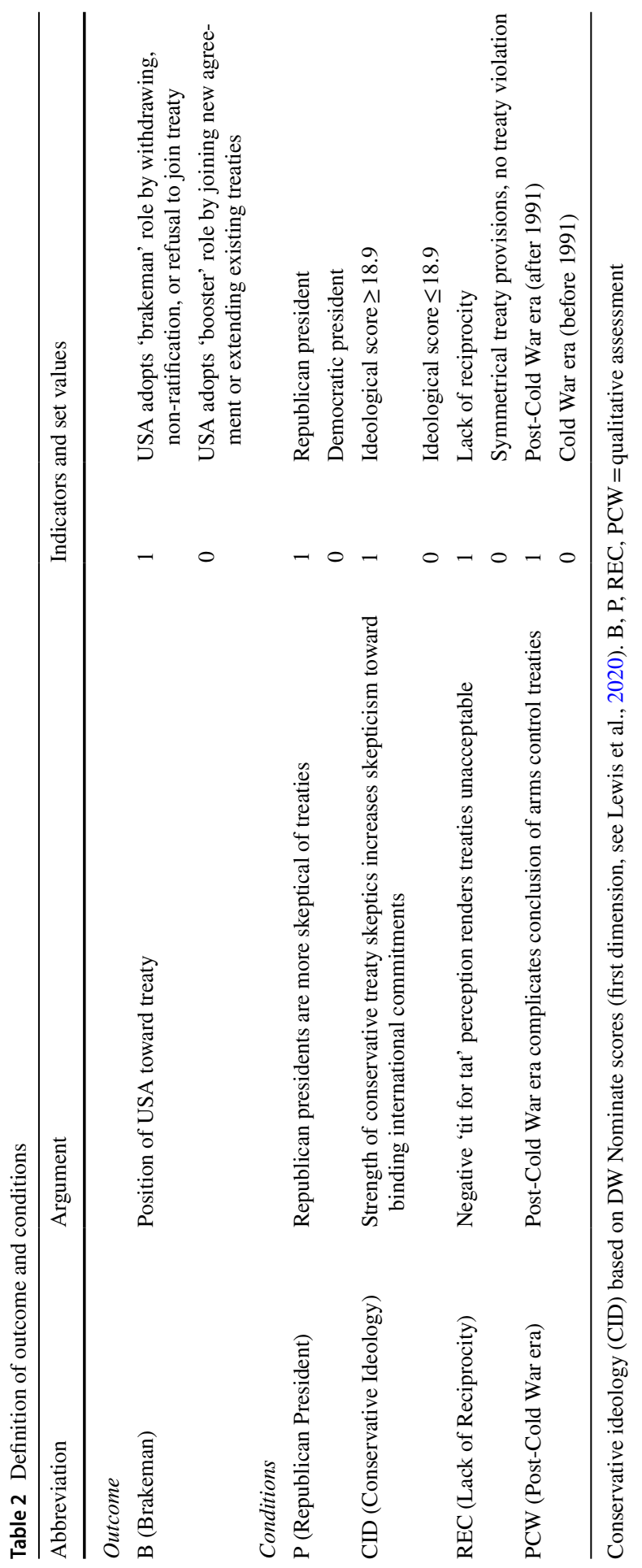

s. 


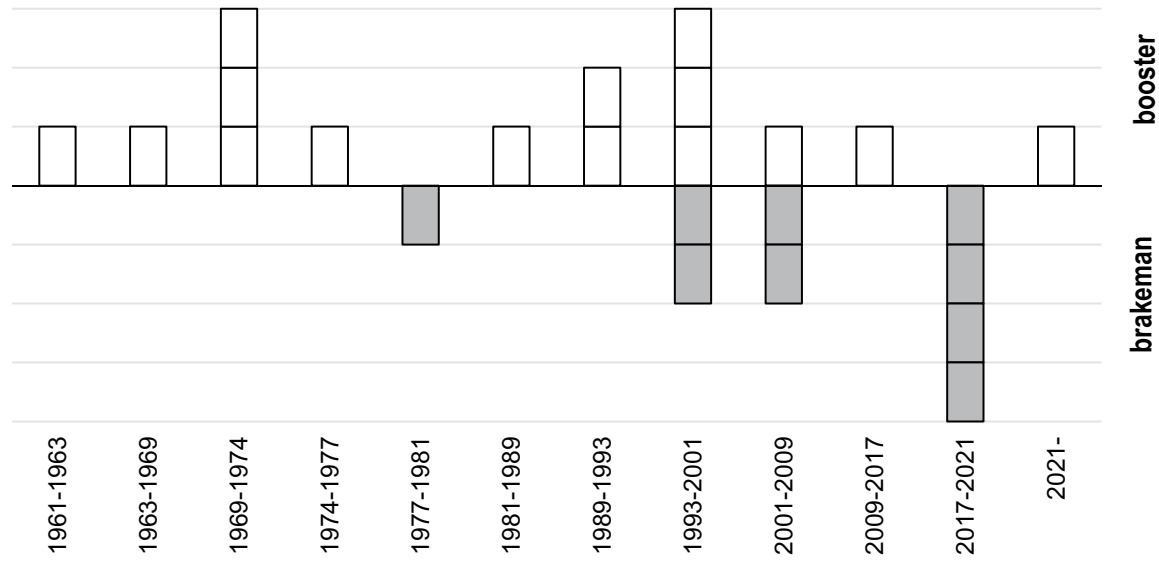

Fig. 2 Timeline of US positioning toward arms control agreements. Note: Blocks above $\mathrm{x}$-axis denote 'booster' cases, and those below the x-axis, 'brakeman' cases. The X-axis is clustered in presidential terms. Source: Own depiction

Table 3 Analysis of necessary conditions for outcome (brakeman) and non-outcome (booster)

\begin{tabular}{|c|c|c|c|c|c|c|}
\hline \multirow[t]{2}{*}{ Conditions } & \multicolumn{3}{|l|}{ Brakeman } & \multicolumn{3}{|l|}{ Booster } \\
\hline & Consistency & $\begin{array}{l}\text { Coverage of } \\
\text { necessity }\end{array}$ & $\begin{array}{l}\text { Relevance of } \\
\text { necessity }\end{array}$ & Consistency & $\begin{array}{l}\text { Coverage of } \\
\text { necessity }\end{array}$ & $\begin{array}{l}\text { Relevance } \\
\text { of necessity }\end{array}$ \\
\hline $\mathrm{P}$ & 0.67 & 0.43 & 0.56 & 0.53 & 0.57 & 0.63 \\
\hline CID & 0.78 & 0.78 & 0.88 & 0.13 & 0.22 & 0.68 \\
\hline REC & 0.78 & 0.88 & 0.94 & 0.07 & 0.13 & 0.70 \\
\hline PCW & 0.89 & 0.53 & 0.56 & 0.47 & 0.47 & 0.53 \\
\hline$\sim \mathrm{P}$ & 0.33 & 0.30 & 0.67 & 0.47 & 0.70 & 0.82 \\
\hline$\sim \mathrm{CID}$ & 0.22 & 0.13 & 0.41 & 0.87 & 0.87 & 0.82 \\
\hline$\sim \mathrm{REC}$ & 0.22 & 0.13 & 0.36 & 0.93 & 0.88 & 0.80 \\
\hline$\sim \mathrm{PCW}$ & 0.11 & 0.11 & 0.65 & 0.53 & 0.89 & 0.94 \\
\hline
\end{tabular}

conduct underground tests. Yet while we cannot do it, we have to comply with this treaty' (Congressional Record, 1999: S12466). Thus, despite President Clinton's support for both treaties, opposition in Congress mounted, and ultimately prevented the ratification of both treaties. ${ }^{8}$

Regarding the condition of a lack of reciprocity, it is important to compare the Mine Ban and CTBT cases to the Chemical Weapons Convention (CWC). The latter

\footnotetext{
${ }^{8}$ Clinton's support for the Ottawa Convention was more ambiguous, though. The president did not sign the agreement, but unilaterally pledged to implement its terms (see Myers, 1998).
} 
treaty can be considered as reciprocal, as it involved all major powers, and was consequently ratified by the same Congress that had rejected the CTBT. At the same time, it is important to consider that the CWC was negotiated under President Bush, which may have muted criticism from the Republican side. ${ }^{9}$

In addition, this path also pertains to the failure to ratify the SALT 2 agreement, which led to the death of the agreement. The traditional bilateral treaty initially received bipartisan support. Democratic President Carter, however, stopped the ratification process after the Soviet Union's invasion of Afghanistan in 1979, which was perceived as a violation of the agreement's spirit (see McGeehan, 1980: 164). SALT 2 therefore represents an outlier case for the Cold War era.

The second solution term consists of the combination of a Republican president and a strong conservative faction in the Senate, which are deemed sufficient for the outcome of the USA acting as a 'brakeman' $\left(\mathrm{P}^{*} \mathrm{CID} \rightarrow \mathrm{B}\right)$. This conjunction of conditions accounts for the decisions to withdraw from the INF (2018) and Open Skies (2020) treaties during the Trump administration. It also accounts for President Trump's withdrawal of the signature to the agreements regarding global arms trades (2019), and the refusal to sign the Nuclear Prohibition Treaty (2017), as well as the agreement on cluster munition, during the Bush administration.

The analysis also identifies two separate paths to explain cases in which the USA favored international treaties, and acted as a 'booster' for international arms control (see Table 5, Fig. 3).

The first solution term applies to treaties ratified under Democratic presidents. In all of these cases, the perception of the agreements as reciprocal, in combination with presidential leadership, was sufficient to adopt a supportive position $\left(\sim \mathrm{P}^{*} \sim \mathrm{REC} \rightarrow \sim \mathrm{B}\right)$. President Obama, for example, faced fierce opposition against the New START Treaty from Republicans, in 2010, and could barely secure the ratification of a traditional 'tit for tat' bilateral arms control treaty. Only after enlisting support from former Republican officials, such as Secretary of State James Baker, and after major concessions to the Republican caucus, increasing his initially proposed budget for modernizing the nuclear arsenal to 85 billion US-Dollars (see Kreps et al., 2018: 480), was Obama able to persuade 13 Republicans, while 26 GOP senators voted against the treaty. Obama here certainly also profited from a broad majority of 57 Democrats in the Senate. Still, it is implausible that Obama would have been able to secure an asymmetrical treaty. This would most certainly have precluded any Republican support (such as in the cases of the Iran deal or the ATT).

The second solution term combines the conditions of a Republican president during the Cold War era, with a weaker conservative faction $\left(\mathrm{P}^{*} \sim \mathrm{CID} * \sim \mathrm{PCW} \rightarrow \sim \mathrm{B}\right)$. This path suggests that conservative presidents have not been consistently against international commitments, in particular during the Cold War era. However, at that time, bipartisanship on arms control agreements was still alive, and conservative skepticism toward international cooperation among Republicans was less

\footnotetext{
9 In addition, Clinton's strained domestic reputation after the Lewinsky affair may have contributed to his inability to convince Republicans to vote in favor of his arms control initiatives (Lantis, 2009: 142).
} 


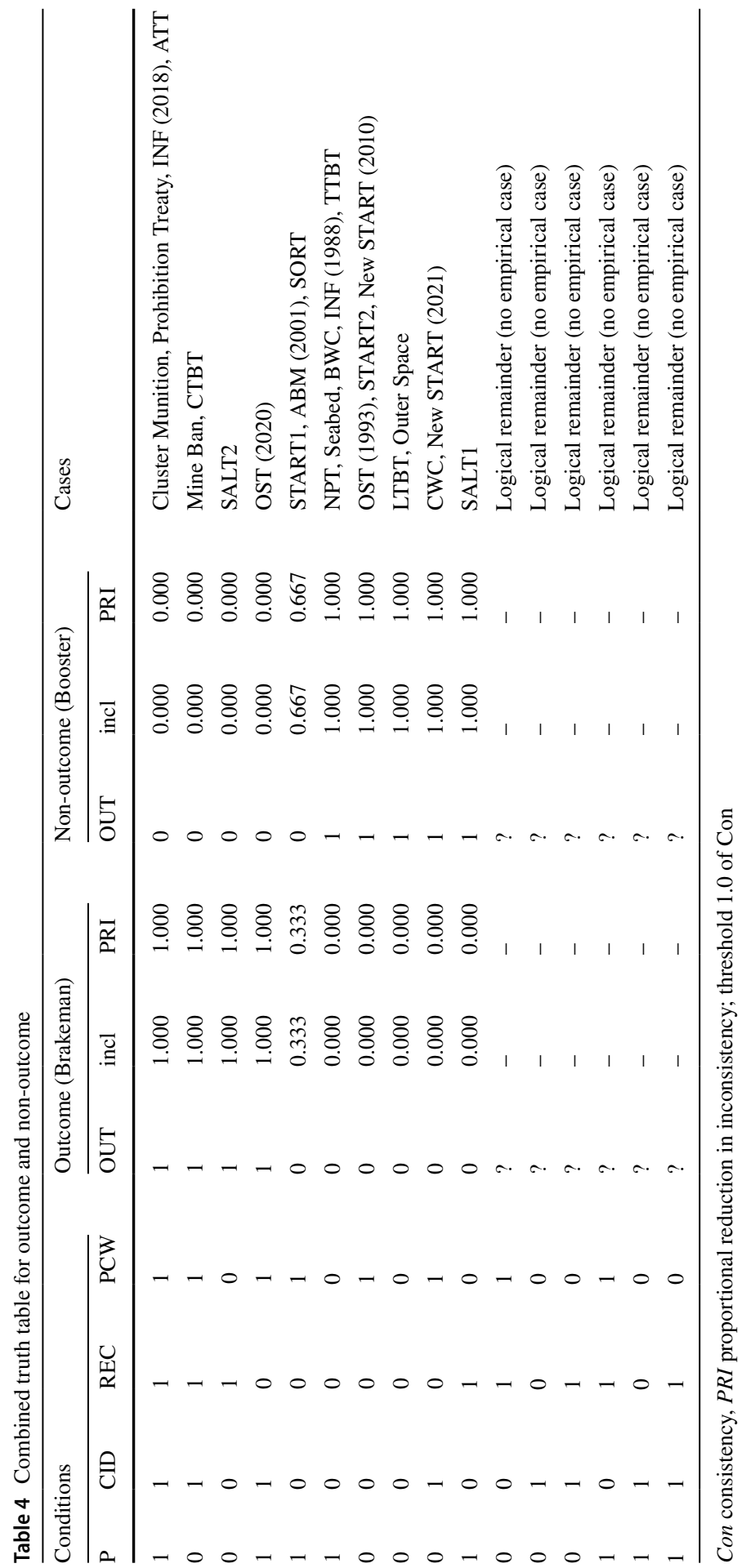




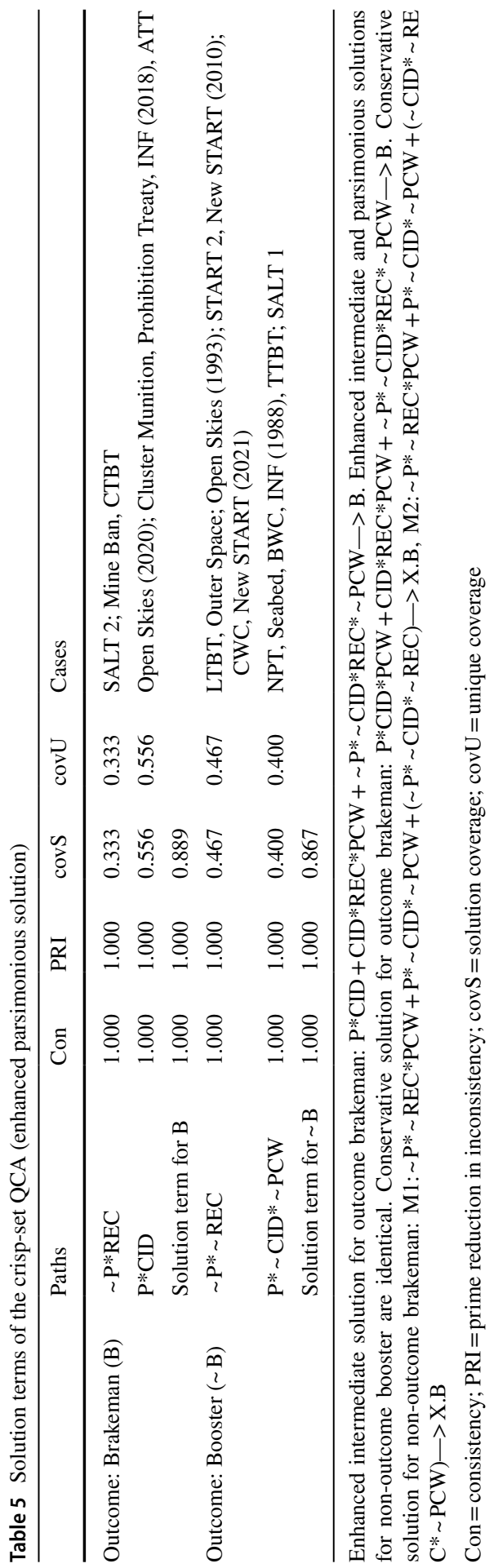

s. 


\begin{tabular}{|c|c|c|c|c|}
\hline \multirow[t]{2}{*}{$\begin{array}{l}\text { Outcome: } \\
\text { Brakeman }\end{array}$} & $\begin{array}{l}\text { Post Cold } \\
\text { War }\end{array}$ & \multirow[t]{2}{*}{$\begin{array}{l}\text { Cons. } \\
\text { Ideol. }\end{array}$} & $\begin{array}{l}\text { Rep } \\
\text { Post Cold } \\
\text { War }\end{array}$ & \multirow[t]{2}{*}{$\begin{array}{l}\text { Cons. } \\
\text { Ideol. }\end{array}$} \\
\hline & Lacl & & Lack of Reciprocity & \\
\hline Cases & SALT 2; & & \multicolumn{2}{|c|}{$\begin{array}{l}\text { OST 2020; Cluster Munition, } \\
\text { Prohibition Treaty, INF 2018, ATT }\end{array}$} \\
\hline
\end{tabular}

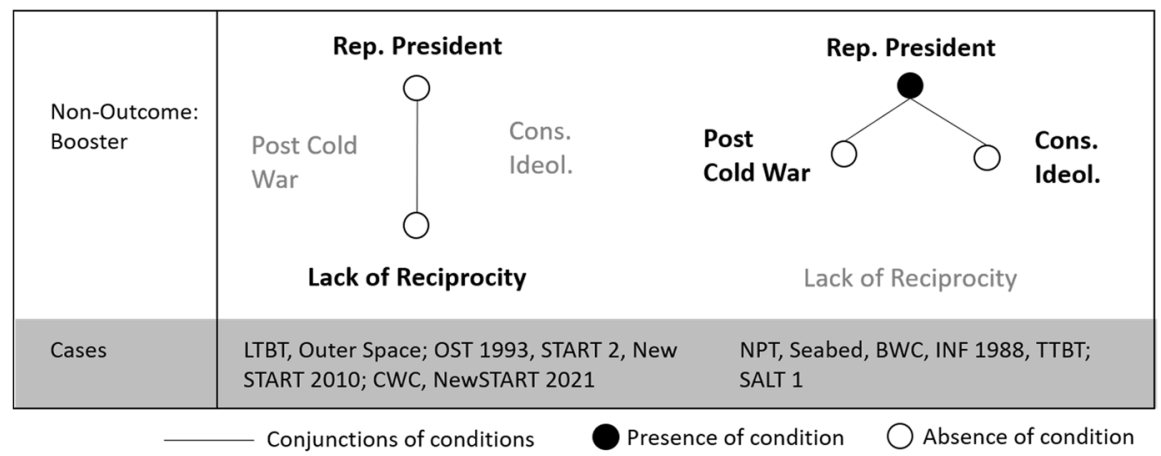

Fig. 3 Enhanced parsimonious solution paths for brakeman and booster role

pronounced. This enabled the bipartisan adoption of major arms control agreements, including SALT 1 (see Kreps et al., 2018: 495), which can be considered as a nonreciprocal agreement.

Overall, the solution terms for the outcome 'brakeman' and the non-outcome 'booster' are highly consistent, and account for 21 out of 24 cases (87.5\%). START 1, under President George H.W. Bush (1991), and the SORT agreement (2002) and the ABM withdrawal (2001) under President Bush, are not covered. As the truth table shows (see Table 4, row 5), these cases share the same conditions, so the QCA research design cannot account for this specific empirical variance.

On closer inspection, START 1 entails similar features of a traditional bilateral arms control treaty, such as the INF or the TTBT, which were concluded under Republican presidents during the Cold War. However, while START 1 was negotiated during the final days of the Cold War, the Senate only gave its 'advice and consent' in 1992, after the dissolution of the Soviet Union had caused a delay. ${ }^{10}$ We can thus consider the agreement as a partial outlier in this set of cases.

Regarding the SORT and ABM cases, the basic argument on the relevance of conservative treaty skeptics also applies. With the termination of the ABM treaty,

\footnotetext{
${ }^{10}$ The dissolution of the Soviet Union created three successor states with nuclear weapons: Ukraine, Kazakhstan, and Belarus. Subsequent negotiations led to the Lisbon Protocol, in which all five states became party to the START agreement.
} 
George W. Bush was able to fulfill a long-held conservative goal regarding the expansion of missile defense systems (see Kubbig, 2005). In this case, it was not a lack of reciprocity in the treaty that contributed to the unilateral withdrawal, but the perceived relative gains in power, which conservatives in Congress and in the administration sought to achieve. Shortly afterwards, Russia and the USA concluded the SORT agreement. Unlike previous agreements, however, SORT entailed few binding restrictions, and no verification regime, and was thus supported even by conservatives in the administration and in Congress.

\section{Treaty politics and the 'America First' doctrine}

In order to assess the plausibility of the QCA, I investigate the Trump administration's positioning regarding arms control in a short case analysis. The four instances of 'brakeman' behavior during the Trump presidency are the Open Skies and INF withdrawals, opposition toward the ATT, and the Prohibition Treaty. The aim of this case vignette is to probe the plausibility of the sufficient conditions identified by the QCA and discuss alternative explanations.

Of the four cases, the Prohibition Treaty is arguably the least relevant. The treaty calls for the abolition of nuclear weapons. While Barack Obama had outlined his vision for a 'Global Zero,' the commitment to a world without nuclear weapons, in Prague in 2009, it is clear that no US president would be willing (or able) to support such a treaty in the foreseeable future.

The ATT is different. The multilateral agreement designed to regulate the international arms trade, was signed by President Obama in 2013 and transmitted to the Senate for ratification in 2016. However, the treaty was tabled, due to the apparent opposition of Republican senators. On the one hand, it is clear that the strength of Republican treaty skeptics foreclosed the ratification of this multilateral treaty during the Obama administration. Already in March 2013, 28 Republican senators introduced a concurrent resolution signaling their intent to block the treaty, which they perceived as posing 'significant risks to the national security, foreign policy, and economic interests of the USA' (S.Con.Res. 7). Nonetheless, the withdrawal was only feasible under a Republican president, whose skepticism toward binding international commitments is well documented. In April 2019, the Trump administration declared the withdrawal of its predecessor's signature, to make clear that the USA would not feel obliged to adhere to the treaty. Trump's justification for his decision hints at a conservative ideological perspective regarding international law, vis-à-vis national interests: 'Under my Administration, we will never surrender American sovereignty to anyone. We will never allow foreign bureaucrats to trample on your Second Amendment freedoms' (White House via Twitter, 2019). The path identified by the QCA, a Republican president backed by conservative treaty skeptics in the Senate $\left(\mathrm{P}^{*} \mathrm{CID} \rightarrow \mathrm{B}\right)$, therefore seems plausible to explain the positioning of the USA as a 'brakeman' of arms control in this case.

In August 2019, the Trump administration announced its intention to withdraw from the bilateral Intermediate-range Nuclear Forces Treaty (INF), which had been 
concluded under President Ronald Reagan in 1987. Among America's European allies, the treaty had been considered as an important cornerstone of the transatlantic arms control regime, as it banned ground-launched missiles with a range of 500-5000 km. Already before President Trump's withdrawal decision, both Republican and Democratic administrations had voiced stern criticism of Russia's behavior within the regime. For example, in 2008, a Russian weapons test raised concern over Moscow's compliance, and US intelligence agencies and the Department of State criticized the Russian Federation for violating the INF treaty (see Kühn and Péczeli, 2017: 75). In 2014, under Barack Obama's presidency, the USA then officially declared that Russia had developed ground-launched SSC-8 cruise missiles, which were prohibited by the 1987 treaty (see Department of State, 2017). The general assessment that Russia was in violation of the INF treaty's prohibition of shortrange and intermediate-range nuclear weapons, was also shared by US NATO allies (NATO, 2018).

Yet, despite this perception of a relevant treaty violation, the Obama administration did not decide to terminate the agreement, but rather sought to induce change within the regime. The Trump administration, in contrast, soon stipulated that the INF treaty would no longer serve US national interests. In his speech in February 2019, Secretary of State Mike Pompeo held that 'Russia has jeopardized the US security interest, and we can no longer be restricted by the treaty while Russia shamelessly violates it' (Pompeo, 2019). Pompeo's speech, as well as other Trump administration statements, for instance, the Department of Defense's Nuclear Posture Review of February 2018, hint at the importance of reciprocity: 'The status quo, in which the USA continues to comply, while Russia continues deployments in violation of the Treaty, is untenable' (Department of Defense, 2018).

Although the Trump administration clearly perceived a lack of reciprocity regarding the INF treaty, this condition is not part of the conjunction of factors deemed sufficient for the outcome of a 'brakeman' role. It should be noted, however, that the Obama administration also criticized Russia's behavior, but sought to continue US participation. Thus, a key condition contributing to the withdrawal of the USA was the Trump administration's ideological orientation, according to which non-reciprocal 'deals' are of particular concern. This perception was also widely supported among conservatives in Congress, and shared by conservative think tanks. For example, a 2015 report by the Heritage Foundation concludes 'that the treaty has outlived its utility, and is no longer in the US interest' (Dodge, 2015). In the Senate, Marco Rubio (R-FL) introduced a resolution in 2014, demanding consequences for Russia's 'arms control violations' (see Rubio, 2014).

The Trump administration's decision to withdraw from the Open Skies also fits into the identified pattern of a Republican president in conjunction with conservative treaty skeptics in the Senate. In fact, conservative Republicans had been campaigning against the agreements for several years (see Richter, 2020: 5). Congressional initiatives taking aim at the Open Skies treaty predate Trump's communicated intent to withdraw from the agreement. In October 2019, Ted Cruz (R-TX) and Mike Cotton (R-AK) introduced S. Res. 388, which calls for a termination of US participation in the multilateral regime, which allows treaty parties to conduct unarmed aerial observation flights over foreign territories. The resolution accuses Russia of 
violating the agreement, and holds that the USA 'does not gain significant additional intelligence from participating in the Open Skies Treaty' (see Congress, 2019; Cotton, 2019).

However, it is important to note that the question of whether Russia violated this agreement remained highly contested between Democrats and Republicans. Even in its formal notice to withdraw from the treaty, the Trump administration did not cite a material breach of the treaty by Russia (see Richter, 2020). Domestically, Democrats sharply criticized President Trump's withdrawal decision, highlighting the polarized perception of arms control policies in the 116th Congress. Robert Menendez (D-NJ), ranking member in the SFRC, complained that the decision would be 'reckless' (cited in Washington Post, 2020). In a letter addressed to the Trump administration, Menendez and other Democrats denounced Trump's decision. Their argumentation contests the perception that Russia's behavior constitutes a relevant violation of the treaty, and thus a clear perception of lacking reciprocity: 'We are aware that implementation of the Open Skies Treaty has been imperfect (...). The issues presented, however, do not negate the positive impact of the Open Skies Treaty' (Foreign Relations Committee, 2020).

This supports the plausibility of the identified paths to a 'brakeman' role. On the one hand, it is highly unlikely that a Democratic administration would have opted to withdraw from the treaty. On the other hand, the Trump administration's nationalist 'America First' doctrine, supported by conservative treaty skeptics in the Senate, can be considered as the main factors behind the positioning of the USA in this case.

In sum, the USA' turn toward a 'brakeman' role on arms control policies under Trump can be traced back to the conservative ideology of a Republican president, who remained consistently skeptical toward binding international commitments, and his congressional allies, who had already been campaigning against existing agreements during the Obama administration.

\section{Conclusion}

The analysis of US treaty politics since 1963 reveals a complex pattern. Both Republican and Democratic presidents have boosted international arms control since the heyday of the Cold War. However, only Republican presidents withdrew from existing agreements, and several Democratic presidents faced fierce opposition from conservative treaty skeptics in the US Senate. At the same time, the perceived treaty 'tit for tat' is an important condition that shapes US treaty behavior. This QCA presented a first step to solve the puzzle of why the US sometimes pushes for international cooperation, and at other times breaks its commitments.

The empirical assessment highlights that the strength of conservative treaty skeptics in the Senate, and within the executive branch, is an important condition influencing US treaty politics. Unlike during the Cold War era, Republicans became increasingly skeptical toward binding international commitments. This criticism aimed at 'assertive multilateralism' in policy areas, such as military interventions, but also applied to the field of arms control, which was previously governed by bipartisan agreement. The turn away from a commitment to 
internationalism, and toward a foreign policy ideology favoring national autonomy and military strength, contributed to the break-up of a consensus in international affairs. Without this consensus, the area of arms control became politicized, and the ability of the USA to perform its traditional role as a guardian of the international arms control regime, became impaired.

The analysis presented here is important in order to understand the sources of polarization of foreign and security policy. In the field of arms control, domestic contestation primarily results from the rise of conservative treaty skeptics within the Republican party, while Democrats' support for international agreements has remained comparably stable over time. Although GOP support for other traditional elements of US foreign policy, such as NATO, has continued, even during the Trump presidency, the preference for arms control agreements has consistently declined among Republicans since the end of the Cold War. Treaties such as the CTBT, New START and the ATT, as well as executive agreements (JCPOA with Iran), have been opposed by a majority of Republicans in the Senate. At the other end of the ideological spectrum, liberal treaty supporters on the Democratic side have been crucial in mobilizing support for treaties, such as New START.

These domestic conditions entail severe consequences for the global role of the USA. It is clear that the Trump administration, and most of its congressional allies, disregarded the possibility of trustful international commitments. At the same time, it is important to note that this development started before the Trump era (see Schultz, 2017: 10-15). Here, my article underscored that the conjunction of conditions at critical junctures - the president's unilateral foreign policy doctrine, in combination with a supportive majority in the Senate-propelled this decline of US leadership. The result of this domestic context is a severe crisis of international arms control. After the break-up of the INF, Open Skies, and JCPOA agreements, the New START treaty is one of the few remaining arms control treaties, after the new Biden administration swiftly moved to extend it.

The contrast between the Trump and Biden administrations reveals an important consequence of the identified polarization: US arms control policies are increasingly volatile, which may complicate negotiations as other actors will question Washington's reliability. Furthermore, the domestic win-set to ratify new agreements remains small, because conservative treaty skeptics maintain a veto position. The remaining option, concluding executive agreements without the Senate's consent, also suffers from reduced reliability. The next conservative administration may again terminate major arms control agreements.

Supplementary Information The online version contains supplementary material available at https://doi. org/10.1057/s41311-021-00330-3.

Acknowledgements I would like to thank the anonymous reviewers for their thoughtful comments. For very valuable feedback and suggestions, I am grateful to Jordan Tama, Gordon Friedrichs and Kenneth A. Schultz. I also benefited from comments by Bernhard Zangl and Markus B. Siewert on earlier drafts of this manuscript.

Funding Open Access funding enabled and organized by Projekt DEAL. The author did not receive any funding for the study. 


\section{Declarations}

Conflict of interest The author declare that they have no conflict of interest.

Open Access This article is licensed under a Creative Commons Attribution 4.0 International License, which permits use, sharing, adaptation, distribution and reproduction in any medium or format, as long as you give appropriate credit to the original author(s) and the source, provide a link to the Creative Commons licence, and indicate if changes were made. The images or other third party material in this article are included in the article's Creative Commons licence, unless indicated otherwise in a credit line to the material. If material is not included in the article's Creative Commons licence and your intended use is not permitted by statutory regulation or exceeds the permitted use, you will need to obtain permission directly from the copyright holder. To view a copy of this licence, visit http://creativecommons.org/licen ses/by/4.0/.

\section{References}

Amirfar, C., and A. Singh. 2018. The Trump Administration and the 'Unmaking' of International Agreements. Harvard International Law Journal 59 (2): 443-459.

Arms Control Association. 2020. Treaties \& Agreements. https://www.armscontrol.org/treaties. Accessed 1 March 2021.

Auerswald, D. 2006. Senate Reservations to Security Treaties. Foreign Policy Analysis 2 (1): 83-100.

Axelrod, R. 1984. The Evolution of Cooperation. New York: Basic Books.

Axelrod, R., and R. Keohane. 1985. Achieving Cooperation Under Anarchy. Strategies and Institutions. World Politics 38 (1): 226-254.

Busby, J., and J. Monten. 2008. Without Heirs? Assessing the Decline of Establishment Internationalism in US Foreign Policy. Perspectives on Politics 6 (3): 451-472.

Busby, J., C. Kafura, and J. Tama. 2020. Multilateralism and the Use of Force: Experimental Evidence on the Views of Foreign Policy Elites. Foreign Policy Analysis 16 (1): 118-129.

Cannon, L. 1980. Reagan: Peace Through Strength. Washington Post, 19 August.

Chaudoin, S., H.V. Milner, and D.H. Tingley. 2010. The Center Still Holds. Liberal Internationalism Survives. International Security 35 (1): 75-94.

Chiampman, A. 2018. SALT Treaty. In: G. Martel (ed.) The Encyclopedia of Diplomacy, online, https:// onlinelibrary.wiley.com/doi/pdf/10.1002/9781118885154.dip10248.

Congressional Record. 1999. Proceedings and Debates of the U.S. Congress. www.congress.gov/congr essional-record. Accessed 1 March 2021.

Congress. 2019. S. Res. 388, https://www.congress.gov/bill/116th-congress/senate-resolution/388/ text?r=259\&s=1. Accessed 1 March 2021.

Congressional Research Service. 2019. Arms Control and Nonproliferation: A Catalog of Treaties and Agreements. https://fas.org/sgp/crs/nuke/RL33865.pdf. Accessed 1 March 2021.

Cotton, T. 2019. The Open Skies treaty is giving Russia spying capabilities: End it. Washington Post. https://www.washingtonpost.com/opinions/2019/12/10/open-skies-treaty-is-giving-russia-spyingcapabilities-end-it/. Accessed 1 March 2021.

Deibel, T.L. 2002. The Death of a Treaty. Foreign Affairs 81 (5): 142-161.

DeLaet, C.J., and J.M. Scott. 2006. Treaty-Making and Partisan Politics: Arms Control and the US Senate, 1960-2001. Foreign Policy Analysis 2 (2): 177-200.

Department of Defense. 2018. Nuclear Posture Review. https://media.defense.gov/2018/Feb/02/20018 72886/-1/-1/1/2018-NUCLEAR-POSTURE-REVIEW-FINAL-REPORT.PDF. Accessed 1 March 2021.

Department of State. 2017. INF Treaty: At a Glance, https://2017-2021.state.gov/inf-treaty-at-a-glance/ index.html. Accessed 1 March 2021.

Dodge, M. 2015. Russian Intermediate-Range Nuclear Forces: What They Mean for the United States, Heritage Foundation, https://www.heritage.org/europe/report/russian-intermediate-range-nuclearforces-what-they-mean-the-united-states. Accessed 1 March 2021. 
Dusa, A. 2019. QCA with R. A Comprehensive Resource. Cham: Springer.

Friedrichs, G. 2021. U.S. Global Leadership Role and Domestic Polarization: A Role Theory Approach. New York: Routledge.

Gabel, J. 2004. The Role of U.S. Nuclear Weapons after September 11. Washington Quarterly 28 (1): 181-195.

Glennon, M. 1990. Constitutional Diplomacy. Princeton: Princeton University Press.

Gries, P.H. 2014. The Politics of American Foreign Policy: How Ideology Divides Liberals and Conservatives over Foreign Affairs. Stanford: Stanford University Press.

Haesebrouck, T., and A. Immerseel. 2020. When Does Politics Stop at the Water's Edge? A QCA of Parliamentary Consensus on Military Deployment Decisions. European Political Science Review 12 (3): 371-390.

Homan, P., and J.S. Lantis. 2020. The Battle for US Foreign Policy: Congress, Parties, and Factions in the 21st Century. New York: Palgrave Macmillan.

Jeong, G.-H., and P.J. Quirk. 2019. Division at the Water's Edge: The Polarization of Foreign Policy. American Politics Research 47 (1): 58-87.

Kelley, J.G., and J. Pevehouse. 2015. An Opportunity Cost Theory of US Treaty Behavior. International Studies Quarterly 59 (3): 531-543.

Kreps, S.E., E.N. Saunders, and K.A. Schultz. 2018. The Ratification Premium: Hawks, Doves, and Arms Control. World Politics 70 (4): 479-514.

Krutz, G.S., and J.S. Peake. 2009. Treaty Politics and the Rise of Executive Agreements: International Commitments in a System of Shared Powers. Ann Arbor: University of Michigan Press.

Kühn, U. 2019. The End of Conventional Arms Control and the Role of US Congress. Journal of Peace and Nuclear Disarmament 2 (1): 253-273.

Kühn, U. 2020. The Rise and Fall of Cooperative Arms Control. Baden-Baden: Nomos.

Kühn, U., and A. Péczeli. 2017. Russia, NATO, and the INF Treaty. Strategic Studies Quarterly 11 (1): 66-99.

Kubbig, B.W. 2005. America: Escaping the Legacy of the ABM Treaty. Contemporary Security Policy 26 (3): 410-430.

Kupchan, C.A., and P. Trubowitz. 2007. Dead Center. The Demise of Liberal Internationalism in the United States. International Security 32 (2): 7-44.

Lantis, J.S. 2009. The Life and Death of International Treaties: Double-Edged Diplomacy and the Politics of Ratification in Comparative Perspective. New York: Oxford University Press.

Lewis, J.B., Poole, K., Rosenthal, H., Boche, A., Rudkin, A. and Sonnet, L. 2020. Voteview: Congressional Roll-Call Votes Database. https://voteview.com/. Accessed 1 March 2021.

Lewis, V. 2017. The President and the Parties' Ideologies: Party Ideas about Foreign Policy Since 1900. Presidential Studies Quarterly 47 (1): 27-61.

McGeehan, R. 1980. Carter's Crises: Iran, Afghanistan and Presidential Politics. The World Today 36 (5): $163-171$.

Mearsheimer, J. 1990. Back to the Future: Instability in Europe after the Cold War. International Security 15 (1): 5-56.

Mello, P.A. 2021. Qualitative Comparative Analysis: Research Design and Application. Washington, D.C.: Georgetown University Press.

Müller, H. 2000. Multilateral Arms Control Treaty Enforcement. Nonproliferation Review 7 (2): 77-90.

Müller, H., and C. Wunderlich, eds. 2013. Norm Dynamics in Multilateral Arms Control: Interests, Conflicts, and Justice. Athens: University of Georgia Press.

Myers, S.L. 1998. Clinton Agrees to Land-Mine Ban, but Not Yet. New York Times. https://www.nytim es.com/1998/05/22/world/clinton-agrees-to-land-mine-ban-but-not-yet.html,.Accessed 1 March 2021.

NATO. 2018. Statement on the Intermediate-Range Nuclear Forces (INF) Treaty. Issued by the NATO Foreign Ministers, Brussels, 4 December. https://www.nato.int/cps/en/natohq/official_texts_161122. htm. Accessed 1 March 2021.

Peake, J.S., G.S. Krutz, and T. Hughes. 2012. President Obama, the Senate, and the Polarized Politics of Treaty Making. Social Science Quarterly 93 (5): 1295-1315.

Pompeo, M. 2019. Remarks to the Press, 1 February, 2019. https://2017-2021-translations.state.gov/2019/ 02/01/remarks-by-michael-r-pompeo-remarks-to-the-press/index.html. Accessed 1 March 2021.

Powell, R. 1991. Absolute and Relative Gains in International Relations Theory. American Political Science Review 85 (4): 1303-1320. 
Prins, B.C., and B.W. Marshall. 2009. Senate Influence or Presidential Unilateralism. An Examination of Treaties and Executive Agreements from Theodore Roosevelt and George W. Bush. Conflict Management and Peace Science 26 (2): 191-208.

Rathbun, B.C. 2011. From Vicious to Virtuous Circle: Moralistic Trust, Diffuse Reciprocity, and the American Security Commitment to Europe. European Journal of International Relations 18 (2): 323-344.

Richter, W. 2020. Attack on the Open Skies Treaty. SWP Comment. https://www.swp-berlin.org/filea dmin/contents/products/comments/2020C29_OpenSkies.pdf. Accessed 1 March 2021.

Rubio, M. 2014. Rubio Introduces Bill Addressing Russian Arms Control Violations. https://www.rubio. senate.gov/public/index.cfm/press-releases?ID=ca02e3f5-fca2-45fb-ac6b-30b5b646ae58. Accessed 1 March 2021.

Schneider, C.Q., and C. Wagemann. 2010. Standards of Good Practice in Qualitative Comparative Analysis (QCA) and Fuzzy-Sets. Comparative Sociology 9: 1-22.

Schneider, C.Q., and C. Wagemann. 2012. Set-Theoretic Methods for the Social Sciences: A Guide to Qualitative Comparative Analysis. Cambridge: Cambridge University Press.

Schultz, K. 2017. Perils of Polarization in US Foreign Policy. Washington Quarterly 40 (4): 7-28.

SIPRI. 2021. Global Nuclear Arsenals Grow as States Continue to Modernize. https://www.sipri.org/ media/press-release/2021/global-nuclear-arsenals-grow-states-continue-modernize-new-sipri-yearb ook-out-now. Accessed 17 June 2021.

Senate Foreign Relations Committee. (2020) Leading Senate Democrats Question Legality of Trump Administration's Withdrawal form Open Skies Treaty, https://www.foreign.senate.gov/press/ranki $\mathrm{ng} /$ release/leading-senate-democrats-question-legality-of-trump-administrations-withdrawal-fromopen-skies-treaty, accessed 1 March 2021.

Twitter. 2019. Tweet by @WhiteHouse, 26 April. https://twitter.com/whitehouse/status/1121846225 827958784?lang=de. Accessed 1 March 2021.

Washington Post. 2020. Trump administration to withdraw from Open Skies treaty in a further erosion of arms control pacts with Russia, 21 May. https://www.washingtonpost.com/national-security/2020/ 05/21/882d460a-9b68-11ea-b60c-3be060a4f8e1_story.html. Accessed 1 March 2021.

White House. 2021. Readout of President Joseph R. Biden, Jr. Call with President Vladimir Putin of Russia, 26 January. https://www.whitehouse.gov/briefing-room/statements-releases/2021/01/26/reado ut-of-president-joseph-r-biden-jr-call-with-president-vladimir-putin-of-russia/. Accessed 1 March 2021.

Washington, B. 2021. Why 'New START' Nuclear Treaty Split Biden From Trump, 28 January, Bloomberg. https://www.bloomberg.com/news/articles/2021-01-28/why-new-start-nuclear-treaty-splitbiden-from-trump-quicktake. Accessed 1 March 2021.

Wenzelburger, G., and F. Böller. 2020. Bomb or Build? How Party Ideologies Affect the Balance of Foreign Aid and Defence Spending. British Journal of Politics and International Relations 22 (1): $3-23$.

Publisher's Note Springer Nature remains neutral with regard to jurisdictional claims in published maps and institutional affiliations. 